\title{
Pathological Evaluation and Nutritional Composition of Golden Melon (Cucumis Melo)
}

\author{
Chuku, E. C. \\ Department of Plant Science and Biotechnology \\ Rivers State University Port Harcourt, Nigeria.
}

Emiri, U. N.

Department Agricultural Education

Isaac Jasper Boro College of Education, Sagbama

Bayelsa State.

Received: July 17, 2018

doi:10.5296/jas.v6i3.13553
Accepted: July 31, 2018

URL: https://doi.org/10.5296/jas.v6i3.13553

\begin{abstract}
Studies on the pathological evaluation and nutritional composition of golden melon was carried out in the Plant Pathology and Food Science and Technology Laboratories in the Rivers State University. The freshly harvested fruits of the golden melon had high amount of

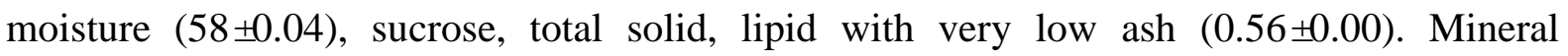
composition analysis also revealed high amount of calcium $(98.5 \pm 0.01)$, moderate quantity of potassium, and low amount of phosphorus (21.4 \pm 0.00$)$. Vitamins A and C were also present in the fruits. Other components found were lactic acid and saponnins which occurred in minute quantities.Pathological evaluation of the associated fungi showed that five different fungi with varying degrees of incidence were associated with the spoilage of the fruits of golden melon. These fungi were Botrytis cinerea (60\%), Aspergillus flavus(30\%), Aspergillus niger and Aspergillus tamari (5\%) respectively while Muccor species recorded the highest incidence $(70 \%)$. However, all the fungal isolates were found to be pathogenic causing soft rot characterized by oozing of water with offensive odour.
\end{abstract}




\section{Introduction}

Cucumis melo L. commonly known as golden melon and honeydew melon is a member of the Cucurbitaceae family alongside other cucurbits like water melon (Citullus lanatus), cucumber (Cucumeropsis mannii), pumpkin (Telfairia occidentalis), etc (Robinson and Decker-Walters, 1999). The common names (golden melon and honeydew melon) were derived from the fruit colour and aroma respectively. The honey dew aroma of the fruit is due to the presence of (Z,Z)-3,6-nonadien-1-ol and phenylethyl alcohol (Perry et al., 2009).The plant has an extensive rooting system, an aerial stem, simple leaf, trailing and creeping habit. The fruit is globular in shape, yellow to gold in colour and attains a size of $12-16 \mathrm{~cm}$. The fruits in turn possess a spherically elongated white seeds (Ajuru and Okoli, 2013).

The Cucurbitaceae family has been implicated by so many researchers to possess high nutritional and medicinal value (Jeffery, 1990). The research of Oluwatoyin and Oluwaseun (2014), showed that the seeds of $C$. melo contains considerable amount of moisture, ash, fibre, fat, protein and carbohydrate. More so, they further revealed the presence of calcium, magnesium, potassium, sodium, copper, manganese, zinc and iron to be present in the seeds as minerals. It has also been reported that the seed oils contains physiochemical properties (Petkova and Antova, 2015; Yanty et al., 2008). Early works have also shown that the fruits are rich in vitamins including riboflavin, A, C, folic acid and thiamine (Eitenmiller et al., 1985; Laur and Tran, 2011). Alam (2016), reported the phenolic contents and antioxidant activities of $C$. melo seeds.

Microorganisms implicated by most researchers on $C$. melo are mostly bacteria including Samonella spp and E. coli (Ukuku et al., 2005). However, Candida spp and Leuconostoc mesenteroides were also reported to be associated with fresh-cut $C$. melo fruits (Zhang, 2013). Adebajo (1993), isolated 19 microorganisms responsible for the spoilage of soft melon ball snacks under tropical conditions in the humid western part of Nigeria and it implicated several fungi organisms viz: Rhizopus arrhizus, R. nigricans, Aspergillus flavus, A. ochraceus, A. tamarii, A. niger, Mucor fragilis and Penicillium citrinum.

It is based on the little information on the nutritional composition and fungi flora of C. melo, this researched was carried out.

\section{Materials and Methods}

\section{Sample Collection}

Samples of healthy fruits of Cucumis melo were bought from fruit vendors at Magboro Junction, Ogun State and brought to the Department of Plant Science and Biotechnology Laboratory Rivers State University, where it was observed for spoilage.

\section{Determination of nutrient components of Cucumis melo}

Healthy samples of Cucumis melo were sent to the Food Science and Technology Laboratory for the determination of nutrient compositions of the entire fruit comprising the pulp and the seeds. The methods of AOAC (2005) was used for the phytochemical analysis. 


\section{Mll Macrothink}

\section{Mycological Studies}

\section{Preparation of mycological medium}

Sterilization of conical flask, slides, Petri dishes and all the equipment needed for the experiment was carried out in the laboratory using the standard methods 9 Agrios, 2005). The mycological medium used was Sabouraud Dextrose Agar prepared in a conical flask using the standard method( Agrios, 2005).

\section{Isolation of fungi from Cucumis melo}

Isolation of fungi was done using the classical phytopathological method whereby small samples of Cucumis melo were cut from points showing visible signs of spoilage to the healthy portions and inoculated onto Sabouraud Dextrose Agar in Petri dishes onto which ampicillin was added to hinder the growth of bacteria. The inoculation was done in triplicate. The inoculated plates were incubated for 5 days at ambient temperature of $25^{\circ} \mathrm{C} \pm 3^{\circ} \mathrm{C}$ (Baudoni, 1988, Chuku, 2009, Samson et al, 1981). The entire set up was observed for 7 days to ensure full grown organisms. Pure culture of isolates were obtained after a series of isolationsand the extent of fungal growth was determined with a meter rule and converted to percentages according to the methods of (Onuegbu, 2002).

\section{Identification of fungal organisms from Cucumis melo}

Microscopic examination of fungal isolates was carried out by the needle mount method (Cheesebrough, 2000). The fungal spores were properly teased apart to ensure proper visibility. The well spread spores were stained with cotton blue in lacto phenol and examined microscopically using both the low and high power objective. The fungi were identified based on their spore and colonial morphology, mycelia structure and other associated structures using the keys of (Samson et al, 1981 and Olds, 1983).

\section{Pathogenicity studies}

Pathogenicity studies was carried out on Cucumis melo to check if the fungi isolated from C.melo were capable of causing spoilage of the fresh samples. The methods of (Agrios, 2005, and Trigiano, 2004) were basically followed. The fungal isolates were introduced using a sterile inoculating loop through a "V" shaped cut on the healthyC.melo and observed for seven days. The set up was monitored daily for growth. 


\section{Ml Macrothink}

\section{Results and Discussion}

Table 1: Proximate composition of $C$. melo

\begin{tabular}{ll} 
Parameters & Percentage composition $(\%)$ \\
\hline Moisture & $58 \pm 0.04$ \\
Ash & $0.56 \pm 0.00$ \\
& \\
Lipids & $15.45 \pm 0.01$ \\
& \\
Carbohydrates & $10.98 \pm 0.03$ \\
Fibre & $2.51 \pm 0.00$ \\
Proteins & $12.5 \pm 0.02$ \\
Total solid & $18.84 \pm 0.01$ \\
Sucrose & $31.12 \pm 0.03$ \\
\hline
\end{tabular}

Table 2: Phytochemical compositions of C. melo

\begin{tabular}{ll}
\hline Parameters & \\
\hline Calcium (mg/100g) & $98.5 \pm 0.01$ \\
Potassium (mg/100g) & $48.6 \pm 0.05$ \\
Phosphorus (mg/100g) & $21.4 \pm 0.00$ \\
Sodium (mg/100g) & $34.2 \pm 0.04$ \\
Vitamin A (I. U.) & $0.91 \pm 0.02$ \\
Vitamin C (mg/100g) & $12.5 \pm 0.01$ \\
Lactic acid (mg/100g) & $0.96 \pm 0.03$ \\
Saponin (mg/100g) & $2.5 \pm 0.00$ \\
\hline
\end{tabular}

Table 3: Fungal isolates andtheir incidence of $C$. melo

$$
\text { Isolate } \quad \text { Percentage incidence (\%) }
$$

\begin{tabular}{ll}
\hline Botrytis cinerea & 60 \\
Aspergillus flavus & 30 \\
& \\
A. niger & 5 \\
A. tamarii & 5 \\
Mucor spp & 70 \\
\hline
\end{tabular}




\section{Macrothink}

Journal of Agricultural Studies

ISSN 2166-0379

2018, Vol. 6, No. 3

The proximate result of $C$. melo as presented in Table 1. revealed the presence of moisture (58 \pm 0.04$)$, ash (0.56 \pm 0.00$)$, lipid (15.45 \pm 0.01$)$, carbohydrate (10.98 \pm 0.03$)$, fibre $(2.51 \pm 0.00)$, protein $(12.5 \pm 0.02)$, total solid $(18.84 \pm 0.01)$ and sucrose $(31.12 \pm 0.03)$. The values for moisture and carbohydrate in this study are higher than that reported by Oluwatoyin and Oluwaseun (2014) for $C$. melo seeds. Meanwhile, the carbohydrate values of $C$. manni and $C$. melo reported by other researchers were higher than $10.98 \pm 0.03$ reported in this study (Fokou et al., 2004; Loukou et al., 2007).

The mineral, vitamin and phytochemical results of $C$. melo presented in Table 2. showed that the fruits contained calcium (98.5 \pm 0.01$)$, potassium (48.6 \pm 0.05$)$, phosphorus $(21.4 \pm 0.00)$, sodium (34.2 \pm 0.04$)$, vitamin A $(0.91 \pm 0.02)$, vitamin C (12.5 \pm 0.01$)$, lactic acid $(0.96 \pm 0.03)$ and saponin (2.5 \pm 0.00$)$. The mineral result of this study disagrees with that reported by Oluwatoyin and Oluwaseun (2014), as lower values of 0.023, 1.04 and 1.77 were reported for calcium, potassium and sodium respectively.

The result of fungal isolates presented in Table 3. implicated five organisms namely Botrytis cinerea, Aspergillus flavus, A. niger, A. tamari and Mucor spp. The pathogenic ability of these organisms proved positive as they were able to cause spoilage when inoculated into fresh healthy samples of $C$. melo. Mucor recorded the highest percentage incidence of $70 \%$. This was immediately followed by Botrytiscinerea (60\%) and Aspergillus flavus (30\%). Nonetheless, the lowest percentage incidence of $5 \%$ was seen for both A. tamari and A. niger.

The fungi isolates of this current study disagrees with that reported by Zhang (2013), as Candida was the only fungus isolated in that research. However, the fungal result of this present study is in line with the report of Adebajo (1993) and Chuku and Adeleke (2008), as all the fungal isolates excluding Botrytis cinerea were implicated to be responsible for the spoilage of soft melon ball snack. Nevertheless, earlier studies have also shown that the isolates of this study have been responsible for the spoilage of other tropical fruits including C. melo relatives in the Cucurbitaceae family.However, it is important to note that fungal infection on plants and plant products are greatly influenced by factors such as handling, transportation and processing methods (Okaka, 1997). In order to reduce the rate contamination by fungi, proper care must be taken to ensure that products are well handled and other related factors that could lead to contamination curbed.

\section{Conclusion}

The fruits of $C$. melo are endowed with so many nutritional values as implicated from the proximate composition analysisthat can support and boost a healthy living when incooperated into diet. The plant is also attacked by fungal organisms that leads to its deterioration and spoilage. Hence proper sanitary measure should be employed when handling the fruits. 


\section{Macrothink}

\section{References}

A.O.A.C., (2005). Official Methods of Analysis of AOAC International. $18^{\text {th }}$ edition. Association ofOfficial Analytical Chemists, Washington, D.C, USA.

Adebajo L. O. (1993). The microbial spoilage of soft melon ball snack under tropical conditions. Molecular Nutrition \& Food Research, 37(4):328-335.

Agrios, G. N., (2005). Plant Pathology, $5^{\text {th }}$ edition. Elsevier Academic Press, USA 383-557.

Alan Z. (2016). Phenolic profile and antioxidant activity of melon (Cucumis melo L.) seeds from Pakistan. Foods, 5(67):1-7.

Baudoni, A.B.A.M., (1988). Diagnosis of disease and proof of pathogenicity (Koch's Postulate) in Laboratory exercises in Plant Pathology. An instructional kit, Baudoni.

Cheesebrough, M., (2000). District Laboratory Practice in Tropical Countries, Part 2. Cambridge University Press, London. 143- 156.

Chuku, E. C and Adeleke, M.T.V. (2008). Preliminary studies on Snake gourd (Trichosanthes cucurmerina) Linn in the Niger Delta. Journal of Research in Bioscience, 4 (2) 28-31.

Chuku E. C. (2009). Fungi responsible for the spoilage of plantain (Musa paradisiaca) at various ripening stage. ActaAgronomica Nigeriana, 9(1\&2) 35-40.

Eitenmiller R. R., Johnson C. D., Bryan D. B. and Gebhardt S. E. (1985). Nutrient composition of cantaloupe and honeydew melons. J. Food Sci., 50:136-138.

Fokou B., Achu M. B. and Chaungues T. M. (2004). Preliminary nutritional evaluation of five species of egusi seeds in Cameroun. African Journal of Nutrition and Agricultural Development, 4:8-12.

Laur L. M. and Tian L. (2011). Provitamin A and vitamin C contents in selected California-grown cantaloupe and honeydew melons and imported melons. J. Food Comps. Anal., 24:194-201.

Loukou A. L., Gnarki Y. D., Kippre A. V., Malice M., Baudoin J. P. and Zoro I. A. (2007). Macronutrient composition of three Cucurbit species cultivated for seed consumption in Cote D'ivoire. African Journal of Biotechnology, 6:529-533.

Okaka, J. C (1997). Tropical Plants Perishables, handling, storage and processing. Pp92. Oluwatoyin H. R. and Oluwaseun T. O. (2014). Nutritional composition and oil characteristics of Golden Melon (Cucumis melo) seeds. Food Science and Quality Management, 27:18-21.

Oluwatoyin, H.R and Oluwaseun, T.O (2014). Nutritional composition and oil characteristics of Golden melon (Cucumis melo) seeds. Food Science and Quality Management, 27: 18-21

Olds R. J., (1983). A colour Atlas of Microbiology, $5^{\text {th }}$ edition, Wolf Medical

Publication Ltd., London 213. 


\section{Macrothink}

Journal of Agricultural Studies

ISSN 2166-0379

2018, Vol. 6, No. 3

Perry P. L., Wang Y. and Lin J. (2009). Analysis of honeydew melon (Cucumis melo var inodorus) flavour and GC-MS/MS identification of (E, Z)-2,6-nonadienyl acetate. Flavour Frag J., 24:341-347.

Petkova Z. and Antova G. (2015). Proximate composition of seeds and oils from melon (Cucumis melo L.) cultivated in Bulgaria. Cogent Food Agric., 1:1018779.

Robinson, R. W. and Decker-Walters, D. S. (1999). Cucurbits. CAB International. Wallingford, Oxford, (UK), pp226.

Samson, R.J, Hoeskstra, E. S and Van Oorschot, C.A.N., (1981). Introduction to food borne fungi. Centraal bureau coor Schmmel cultures, Netherlands. 16 -170. Publisher Institute of Royal, Netherland.

Trigiano, R. N, Windham, M. J and Windham, A.S., (2004). Plant Pathology concept and Laboratory exercise. C.R.C. Press L.L.C, USA. 345-359.

Ukuku D. O., Bari M. L., Kawamato S. and Isshiki K. (2005). Use of hydrogen peroxide in combination with nisin, sodium lactate and citric acid for reducing transfer of bacteria pathogens from whole melon surfaces to fresh-cut pieces. Int. J. Fd. Microbiol., 104:225-233.

Yanty N. A. M., Lai O. M. Osman A., Long K. and Ghazali H. M. (2008). Physiochemical properties of Cucumis melo var. inodorus (honeydew melon) seed and oil. J. Food Lipids, $15: 42-55$.

Zhang B. Y. (2013). Evaluation of modified atmospheres as a preservation tool for fresh-cut fruit. PhD dissertation, Faculty of Bioscience Engineering, Ghent University, Ghent. Pp169.

\section{Copyright Disclaimer}

Copyright for this article is retained by the author(s), with first publication rights granted to the journal.

This is an open-access article distributed under the terms and conditions of the Creative Commons Attribution license (http://creativecommons.org/licenses/by/4.0/). 